\title{
Urogastrone and Lactose Concentrations in Precolostrum, Colostrum, and Milk
}

\author{
J. M. BEARDMORE ${ }^{(36)}$ D. I. LEWIS-JONES, AND R. C. RICHARDS ${ }^{(37)}$ \\ Department of Medical Cell Biology and Department of Anatomy, University of Liverpool, \\ Liverpool, United Kingdom
}

\begin{abstract}
Summary
The concentration of urogastrone (URO) and lactose was measured in breast secretions from four women. URO levels were high in precolostrum and fell markedly around the time of parturition to relatively constant low levels in mature milk. When milk samples were fractionated on a Biogel P10 column, the major peak of immunoreactivity occurred at the point at which pure URO eluted.

There was good correspondence between the fall in URO levels at birth and the increase in lactose levels, suggesting that the decrease in URO was a dilution effect as the osmotic influence of lactose increased.
\end{abstract}

\section{Abbreviations}

EGF, epidermal growth factor

RIA, radioimmunoassay

URO, urogastrone

Human milk is a food source specifically tailored to the needs of the newborn infant and fulfills all the child's nutritional requirements for the first 4-6 months of life and up to three-quarters of his needs from 6-12 months of age (33). For a great many years cow's milk has substituted for human milk in feeding the newborn infant. With this use came an interest in comparing the composition of the two milks in an attempt to justify the continued use of this substitution (for reviews see 15 and 32); however, it is now commonly accepted that human milk is of greater nutritional value in feeding the newborn infant than cow's milk $(1,21)$. Furthermore, milk does not just fulfill a nutritional role, but contains antibody molecules and other antimicrobial factors that are involved in the transfer of passive immunity $(27,28)$, and hormones and growth factors of unknown function $(3,23,31)$. The concentration of hormones and growth factors in milk varies between species, presumably reflecting the varying needs of the neonate. Although we do not understand the role these molecules play in the neonate, it becomes important to compare their levels throughout lactation.

In the study to be reported here we monitored the concentration of URO (the human equivalent of mouse EGF) in precolostrum, colostrum, and mature milk, from human donors.

\section{MATERIALS AND METHODS}

Milk samples. Milk was obtained from five individuals at various stages of pregnancy and lactation. Samples from four of the volunteers (CK, AR, JL, and KD) were supplied during antenatal and postnatal periods and were assayed after up to 12 months in storage at $-40^{\circ} \mathrm{C}$. The 5 th donor $(\mathrm{CL})$ only provided mature milk samples, and these were assayed within 4-8 wk of collection.
Milk was manually expressed into the sterile universal containers provided, and stored in a domestic freezer compartment until they were transferred to storage at $-40^{\circ} \mathrm{C}$ in the laboratory. Samples were centrifuged at $9000 \times g$ in a Microfuge (Beckman RIIC Ltd.) and the aqueous phase withdrawn from below the floating lipid layer and assayed for URO activity.

For the purposes of this study, we considered all milk produced before delivery as being precolostrum, milk produced during the first $48 \mathrm{~h}$ after delivery as colostrum, and milk produced after the first $48 \mathrm{~h}$ postpartum as mature milk. Donors CK, AR, and JL who were hypersecretory produced greater volumes of precolostrum than KD who had to collect small samples of precolostrum over many expressions to give weekly samples.

$U R O$ radioimmunoassay. An homologous, highly sensitive radioimmunoassay (RIA) for URO has previously been described in detail (13) and was employed for this study. Pure URO and its antiserum were kindly supplied by Dr. H. Gregory (I.C.I. Pharmaceuticals, Alderley Edge, U.K.).

Iodination of URO was by a modification of the chloramine $\mathrm{T}$ method of Hunter and Greenwood (20). One microgram amounts were iodinated and free iodine was separated from labelled URO by fractionation on a Biogel P6 column. The iodinated URO had a mean specific activity of $184 \mu \mathrm{Ci} / \mu \mathrm{g}$ and was stored at $-20^{\circ} \mathrm{C}$ for up to $3 \mathrm{wk}$. The label was diluted immediately before use and approximately $15 \mathrm{pg}$ of starting peptide was incubated per assay tube.

Antibody bound and free label was separated by the addition of goat anti-rabbit serum and milk samples were assayed at dilutions of 1:20 to 1:200 depending on their URO content. When milk at these dilutions was incubated with the label and a large excess of antibody, there was no change in total binding compared to that when milk was absent. Standardised samples of urine (54 $\mu \mathrm{g} /$ litre) were included in each assay, and in effect provided a second standard curve.

Lactose assay. Defatted milk samples were assayed for lactose content by the method of Kottler, Tierney, and Rosensweig (24). The majority of milk samples were assayed in a minimum of three assays (subject to sample size), and at dilutions of 1:40 or 1:80 in $0.1 \mathrm{M}$ potassium phosphate buffer, $\mathrm{pH}$ 7.2.

\section{RESULTS}

Radioimmunoassay characteristics. The RIA for URO used in this study was sensitive to $50 \mathrm{pg}$ per sample and inter- $(27 \%)$ and intraassay $(6 \%)$ variations were calculated according to Rodbard (29), on a series of diluted milk samples. Dilution dose response curves for human milk (dilutions of 1:20 to 1:100) and urine were parallel to that of the pure URO standards (Fig. 1).

Milk URO concentrations. A comparison of URO concentrations in mature milk after long term (12 months) and short term 
(4-8 wk) storage showed no significant difference suggesting that long term storage of samples had no effect on the measurement of URO by RIA.

For three of the individuals (CK, AR, JL) whose milk samples were studied in detail, URO concentrations were high in preco-

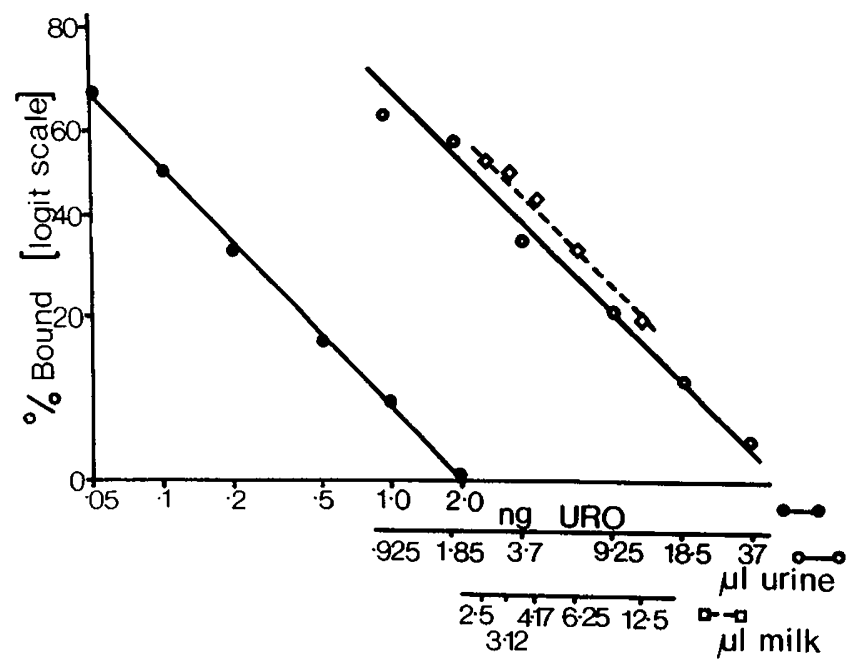

Fig. 1. Comparison of inhibition curves produced by urogastrone standards and serial dilutions of milk and urine samples. Ordinate Axis: \% Bound (logit scale $=\log _{\mathrm{e}} \%$ bound $/ 100-\%$ bound) and $A$ bcissa: $\log _{\mathrm{e}}$ standard concentration or volume of sample. lostrum $(130-800 \mathrm{ng} / \mathrm{ml})$ and fell markedly around the time of parturition to relatively constant low levels in mature milk (20$111 \mathrm{ng} / \mathrm{ml}$, Fig. 2). Colostrum concentrations of URO varied extensively $(35-438 \mathrm{ng} / \mathrm{ml})$ depending on the time, pre- or postpartum, when colostrum levels started to fall down to those found in mature milk (Fig. 2).

When pooled precolostrum or mature milk samples were fractionated on a Biogel P10 column, the major peak of immunoreactivity occurred at the point at which pure standard URO eluted (Fig. 3). This accounted for the majority of the assayable URO in parallel unfractionated samples. A small peak of immunoreactivity occurred in the void volume, but this only represented very low levels of material. Indeed, the fractions under this peak appeared cloudy, indicating the presence of high concentrations of large milk proteins, and this may be giving rise to non-specific interference in the RIA.

Milk lactose concentrations. The standard curve for lactose was linear between 12.5 and 500 nmole per sample, and for a series of diluted milk samples, the intraassay variation was calculated to be $2.4 \%$ and the interassay variation $25 \%$. The lactose levels in the milk from donor AR increased through birth and showed good correlation with the reduction in URO concentration at this time (Fig. 2). Although the URO concentrations measured in samples from donor $\mathrm{JL}$ decreased prepartum this again was accompanied by a corresponding increase in lactose levels; however, in this individual lactose levels decreased again before continuing to rise postpartum (Fig. 2).

In contrast to the other donors, URO concentrations in samples from donor CK were extremely variable and decreased through birth down to low levels in mature milk. This fall in URO
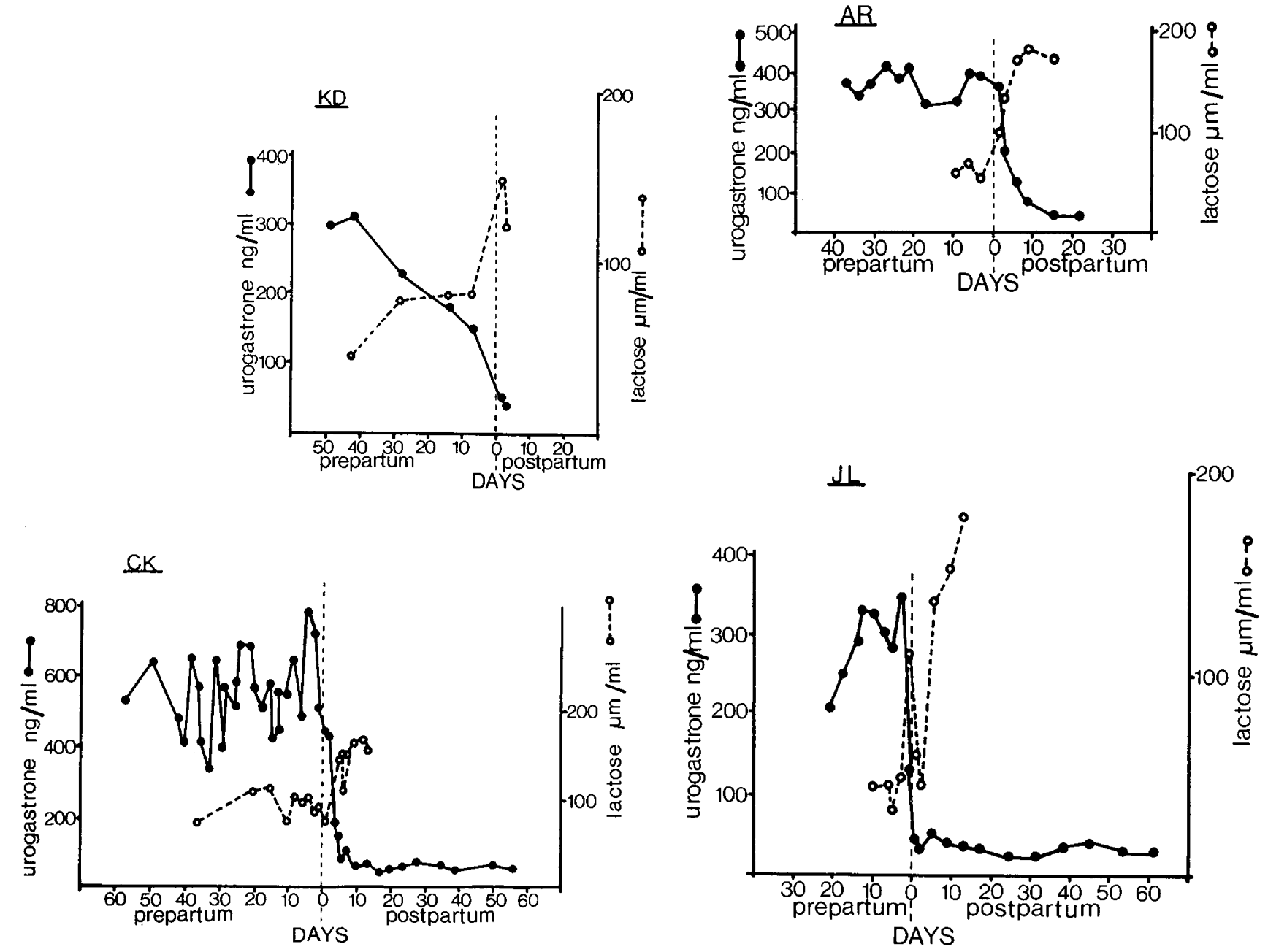

Fig. 2. Urogastrone and lactose concentrations in milk samples from the four human donors (KD, CK, AR, and JL) studied in detail. 


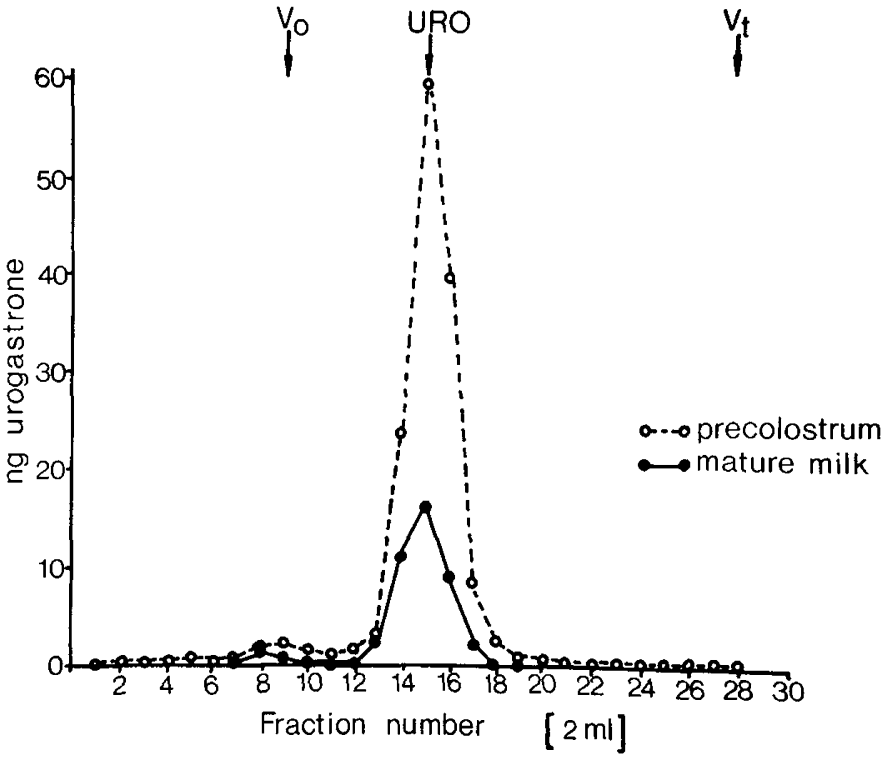

Fig. 3. Biogel P10 chromatography (column size $1.7 \times 25 \mathrm{~cm}$ ) of pooled precolostrum $(175 \mu \mathrm{l})$ and mature milk $(700 \mu \mathrm{l})$ from donor $\mathrm{CK}$, applied as a diluted $2.5 \mathrm{ml}$ sample in eluent buffer at $4^{\circ} \mathrm{C}$.

concentration partially correlated with the postpartum rise in lactose levels (Fig. 2). The normal secretor (KD) had milk URO levels which fell slowly throughout the prepartum period and during birth. This showed an inverse correlation with the slow rise in lactose levels throughout the prepartum period (Fig. 2).

\section{DISCUSSION}

URO in human milk has been shown to be biologically active when assayed on fibroblasts in tissue culture (6). The concentrations of this peptide measured in precolostrum in this study were very high and represent the most concentrated source of URO so far detected $(14,19,31)$. Invariably, there was a reduction in URO concentration either before or during the colostral phase and this correlated with the reported reduction in levels of antimicrobial factors in the same milk samples (28). This reduction resulted in donors $\mathrm{CK}$ and $\mathrm{AR}$ supplying their neonates with a concentrated package of URO in colostrum during the first $48 \mathrm{~h}$ postpartum; however, colostrum levels reported for donors $\mathrm{JL}$ and $\mathrm{KD}$ were much lower and similar to those for mature milk. Concentrations of URO measured in mature milk were relatively low and compared favourably with the already reported level of $80 \mathrm{ng} / \mathrm{ml}$ (31); however, the increased volume of milk supplied to the neonate during established lactation would result in the gastrointestinal tract being exposed to a relatively large amount of URO.

The reduction in levels of other milk components just after birth has been shown to be due to the rise in milk lactose concentrations during this period (16); however, as some of our donors showed a decrease in URO concentration before birth we thought it necessary to measure lactose levels at this time in an attempt to explain the prepartum drop in URO concentration. Lactose levels in precolostrum, colostrum, and mature milk were similar to those already reported $(16,25)$. In two of the women (AR and JL) the decrease in URO concentration was matched or preceeded by an increase in the lactose concentration in the samples. This was also true for (CK) if one considered the drop in URO levels just before birth to be part of the overall variability in URO concentrations observed in precolostrum samples from this individual. The gradual decrease in URO concentration in the prepartum period in the normal secretor $(\mathrm{KD})$ was matched by a gradual increase in milk lactose concentration; however, the URO levels in precolostrum reported for this individual were in general lower than those measured in the other three hypersecre- tors and this was in direct contrast to the already reported high levels of antimicrobial factors in precolostrum from this donor (28). The pattern of URO levels in breast secretions i.e., high in precolostrum, falling during colostrum formation, with a steady but decreased level maintained in mature milk was similar to that obtained for immunoglobulins A, G, M, lactoferrin, $\alpha_{1}$-antitrypsin, complement components $\mathrm{C} 3, \mathrm{C} 4$, and lysozyme, measured in the same milk samples (28). In addition, when growth factor concentrations were measured via a radioreceptor assay (in competition with $\left.\left[{ }^{125} \mathrm{I}\right]-\mathrm{EGF}\right)$ they showed a similar pattern in bovine, ovine, and goat mammary secretions (K. Brown personal communication). Whether these growth factors represent EGF/URO is not yet clear. In contrast, the pattern of EGF in mouse milk is entirely different (3) probably reflecting the varying needs of the neonate in different species.

Milk URO probably originates from serum, as close-arterial infusion of $\left[{ }^{125} \mathrm{I}\right]-E G F$ resulted in a significant uptake of this peptide by the mammary gland of the goat and transport into milk (4). EGF/URO would seem to be ideally suited to play a role in the gut as it is not affected by low $\mathrm{pH}$ and survives limited proteolytic digestion (12). The mitogenic action of EGF/URO both in vivo and in vitro has been well documented (7) and indeed an increase in DNA content of the small intestine was reported $(17,34)$, when neonates were fed colostrum as an alternative to water or an isocaloric artificial formula. Furthermore, there is a large amount of evidence to show that EGF/URO exerts a trophic effect on the mucosa of the stomach and small intestine of both adult and neonatal animals $(2,5,9,10,22,26,30)$. Although URO has also been localized in Brunner's gland in the adult human duodenum (18), its presence in the newborn has not been investigated.

Gregory (11) first identified URO by its ability to inhibit gastric acid secretion after intravenous administration; however, recent evidence in adult rats suggests that when EGF/URO is given intragastrically it is unable to alter gastric acid secretion (8). The URO in milk may therefore have no role to play in lowering the $\mathrm{pH}$ of the stomach contents but could still exert a growth-promoting effect on the gastrointestinal tract of the neonate.

\section{REFERENCES AND NOTES}

1. Alais, C. and Blanc, B.: Milk proteins: biochemical and biological aspects. World Rev. Nutr. Diet., 20: 66 (1975).

2. Al-Nafussi, A. I. and Wright, N. A.: The effect of epidermal growth factor (EGF) on cell proliferation of the gastrointestinal mucosa in rodents. Virchows Arch. B. Cell Pathol., 40: 63 (1982).

3. Beardmore, J. M. and Richards, R. C.: Milk epidermal growth factor concentrations in the mouse throughout lactation. J. Endocrinol., (in press) (1982).

4. Blakeley, D. M., Brown, K. D., and Fleet, I. R.: Transfer of epidermal growth factor from blood to milk in lactating goats. J. Physiol., 326:82P (1982).

5. Calvert, R., Beaulieu, J.-F., and Ménard, D.: Epidermal growth factor (EGF) accelerates the maturation of fetal mouse intestinal mucosa in utero. Experientia, 38: 1096 (1982).

6. Carpenter, G.: Epidermal growth factor is a major growth-promoting agent in human milk. Science, 210: 198 (1980).

7. Carpenter, G. and Cohen, S.: Epidermal growth factor. Ann. Rev. Biochem., 48: 193 (1979).

8. Dembinski, A., Gregory, H., Konturek, S. J., and Polanski, M.: Trophic action of epidermal growth factor on the pancreas and gastroduodenal mucosa in rats. J. Physiol. (Lond.), 325: 35 (1982).

9. Feldman, E. J., Aures, D., and Grossman, M. I.: Epidermal growth factor stimulates ornithine decarboxylase activity in the digestive tract of the mouse. Proc. Soc. Exp. Biol. Med., 159; 400 (1978).

10. Forgue-Lafitte, M-E., Laburthe, M., Chamblier, M-Cl., Moody, A. J., and Rosselin, G.: Demonstration of specific receptors for EGF-Urogastrone in isolated rat intestinal cells. FEBS Lett., 114: 243 (1980).

11. Gregory, H.: Isolation and structure of urogastrone and its relationship to epidermal growth factor. Nature (Lond.), 257: 325 (1975).

12. Gregory, H., Bower, J. M., and Willshire, I. R.: Urogastrone and epidermal growth factor. In: K. W. Kastrup and J. H. Neilsen: Growth Factors. 11th FEBS Meeting. p. 75 (Pergamon Press, New York, 1978).

13. Gregory, H., Holmes, J. E., and Willshire, I. R.: Urogastrone-epidermal growth factor. In: B. M. Jaffe and H. R. Behrman: Methods of Hormone Radioimmunoassay. 2nd Ed. p. 927 (Academic Press, New York, 1979).

14. Gregory, H., Walsh, S., and Hopkins, C. R.: The identification of urogastrone in serum, saliva, and gastric juice. Gastroenterology, 77: 313 (1979).

15. Hansen, R. G.: Milk in human nutrition. In: B. L. Larson and V. R. Smith: Lactation: A comprehensive treatise. Vol. 3. p. 281 (Academic Press, New York, 1974). 
16. Healy, D. L., Rattigan, S., Hartman, P. E., Herington, A. C., and Burger, H. G.: Prolactin in human milk: correlation with lactose, total protein, and $\alpha$-lactalbumin levels. Am. J. Physiol., 238: E83 (1980).

17. Heird, W. C. and Hansen, I. H.: Effect of colostrum on growth of intestinal mucosa. Pediatr. Res., 11: 406 (1982).

18. Heitz, P. U., Kasper, M., Van Noorden, S., Polak, J. M., Gregory, H., and Pearse, A. G. E.: Immunohistochemical localisation of urogastrone to human duodenal and submandibular glands. Gut, 19: 408 (1978).

19. Hirata, Y. and Orth, D. N.: Epidermal growth factor (urogastrone) in human tissues. J. Clin. Endocrinol. Metab., 48: 667 (1979).

20. Hunter, W. M. and Greenwood, F. C.: Preparation of iodine-131 labelled human growth hormone of high specific activity. Nature (Lond.), 194: 495 (1962)

21. Jellife, D. B., Gurney, M., and Jellife, E. F. P.: Prognosis for the undernourished surviving child. In: A. Chavez, H. Bourges, and S. Basta: Nutrition. Vol. 2. p. 77 (S. Karger, Basel, 1975).

22. Johnson, L. R. and Guthrie, P. D.: Stimulation of rat oxyntic gland mucosal growth by epidermal growth factor. Am. J. Physiol., 238: G45 (1980).

23. Koldovsky, O.: Hormones in milk. Life Sci., 26: 1833 (1980).

24. Kottler, D. P., Tierney, A. R., and Rosensweig, N. S.: An enzymatic microassay for lactose. Anal. Biochem., 110: 393 (1981).

25. Kulski, J. K., Smith, M., and Hartman, P. E.: Perinatal concentrations of progesterone, lactose and $\alpha$-lactalbumin in the mammary secretion of women. J. Endocrinol, 74: 509 (1977)

26. Malo, C. and Ménard, D.: Influence of epidermal growth factor on the development of suckling mouse intestinal mucosa. Gastroenterology, 83: 28 (1982).

27. McClelland, D. B. L., McGrath, J., and Samson, R. R.: Antimicrobial factors in human milk. Acta Paediatr. Scand. (Suppl.) 271: 3 (1978)
28. Lewis-Jones, D. I. and Reynolds, G. J.: A suggested role for precolostrum in preterm and sick newborn infants. Acta Paediatr. Scand., 71: (in press) (1982)

29. Rodbard, D.: Statistical quality control and routine data processing for radioimmunoassay and immunoradiometric assays. Clin. Chem., 20: 1255 (1974).

30. Scheving, L. A., Yeh, Y. C., Tsai, T. H., and Scheving, L. E.: Circadian phasedependent stimulatory effects of epidermal growth factor on deoxyribonucleic acid synthesis in the duodenum, jejunum, ileum, caecum, colon, and rectum of the adult male mouse. Endocrinology, 106: 1498 (1980)

31. Starkey, R. H. and Orth, D. N.: Radioimmunoassay of human epidermal growth factor (urogastrone). J. Clin. Endocrinol. Metab., 45: 1144 (1977).

32. Vorherr, H.: Human lactation and breast feeding. In: B. L. Larson: Lactation: A Comprehensive Treatise. Vol. 4. p. 181 (Academic Press, New York, 1978).

33. Wade, N.: Bottle-feeding: adverse effects of a western technology. Science, 184: 45 (1974).

34. Widdowson, E. M., Colombo, V. E., and Artavanis, C. A.: Changes in the organ of pigs in response to feeding for the first 24 hours after birth. II. The digestive tract. Biol. Neonate, 28: 272 (1976).

35. The authors are grateful to E. Joughin and R. Burniston for technical assistance, the Liverpool Branch of the National Childbirth Trust and the Staff of Wards $A$ and $\mathrm{E}$ of the Oxford Street, Liverpool Maternity Hospital for their assistance with recruitment.

36. J. M. B. was in receipt of a Liverpool University Studentship.

37. Requests for reprints should be addressed to: Dr. Clive Richards, Department of Medical Cell Biology, P.O. Box 147, The University, Liverpool, L69 3BX England.

38. Received for publication September 2, 1982.

39. Accepted for publication March 10, 1983.

\title{
On the Biologic Origin of $\mathrm{C}_{6}-\mathrm{C}_{10}$-Dicarboxylic and $\mathrm{C}_{6}-\mathrm{C}_{10}-\omega-1-\mathrm{Hydroxy}$ Monocarboxylic Acids in Human and Rat with Acyl-CoA Dehydrogenation Deficiencies: in Vitro Studies on the $\omega$ - and $\omega$-1-Oxidation of Medium-Chain $\left(\mathrm{C}_{6}-\mathrm{C}_{12}\right)$ Fatty Acids in Human and Rat Liver
}

\author{
N. GREGERSEN, ${ }^{(41)}$ P. B. MORTENSEN, AND S. KøLVRAA
}

Research Laboratory for Metabolic Disorders, University Department of Clinical Chemistry, Aarhus Kommunehospital and Institute of Human Genetics, University of Aarhus, DK-8000 Aarhus C, Denmark

\section{Summary}

$\mathrm{C}_{6}-\mathrm{C}_{10}$-dicarboxylic and $\mathrm{C}_{6}-\mathrm{C}_{10}-\omega-1$-hydroxy monocarboxylic acids were measured in postmitochondrial $(10,000 \mathrm{~g})$ fractions of rat liver after incubation with hexanoic, octanoic, and decanoic acids. In livers both from fed and starved rats, the proportion of decanoic acid converted to sebacic acid was high (approximately $25 \%$ ) with only minor accumulation of the intermediate 10-hydroxy decanoic acid (1-2\%). The conversion of octanoic and hexanoic acids to suberic and adipic acids, respectively, was low $(<1 \%)$. The intermediate 8-hydroxy octanoic and 6-hydroxy hexanoic acids were also accumulated in very small amounts $(<1 \%)$. It was concluded that cytochrome-P-450-mediated $\omega$-hydroxylation was of decisive importance for the production rate of the dicarboxylic acids. Analysis of kinetic parameters of human and rat liver microsomal $\omega$ - and $\omega$-1-hydroxylation of hexanoic, octanoic, decanoic, and dodecanoic acids gave the following results: in rats, the apparent $\mathrm{Km}$ values for the $\omega$-hydroxylation for dodecanoic and decanoic acids are low, i.e., 171 and $3.1 \mu \mathrm{mole} / \mathrm{liter}$, respec- tively, whereas they are high for octanoic and hexanoic acids (8211 and $8822 \mu \mathrm{mole} /$ liter, respectively). In two different humans, the corresponding $\mathrm{Km}$ values for dodecanoic, decanoic, octanoic, and hexanoic acids are 3.6-186, 522-247, 4861-3892, and 6825-10400 $\mu \mathrm{mole} / \mathrm{liter}$, respectively. Based on these results, it is argued that adipic and suberic acids found in urine from rats and humans with acyl-CoA dehydrogenation deficiencies are not biosynthesized by direct $\omega$-oxidation of hexanoic and octanoic acids, but most probably by means of $\boldsymbol{\beta}$-oxidation of sebacic and dodecanedioic acids, produced by direct $\omega$-oxidation.

The affinities of the $\omega$-1-hydroxylation systems for the four monocarboxylic acids is similar in rats and humans. The apparent $\mathrm{Km}$ values for dodecanoic acid in rats and in the two human livers are low, i.e., 139 and 92-131 $\mu$ mole/liter, respectively. The $\mathrm{Km}$ values for decanoic, octanoic, and hexanoic acids are all high in both rats and humans, i.e., in the range from $638 \mu$ mole/liter (for decanoic in one of the human livers) to more than $20,000 \mu$ mole/ liter (for hexanoic acid in both species). It is argued that 5-hydroxy hexanoic, 7-hydroxy octanoic, and 9-hydroxy decanoic acids found 